Jurnal IImiah Iqra'

2541-2108 [Online] 1693-5705 [Print]

Tersedia online di: http://journal.iain-manado.ac.id/index.php/JI/issue/view/176

\title{
Penerapan Model Pembelajaran Kooperatif Tipe Teams Games Tournament (TGT) Untuk Meningkatkan Aktivitas dan Hasil Belajar IPA Peserta Didik Kelas VIII Taksifi 1 MTs. Negeri 1 Manado
}

\author{
Marlina Maladjim \\ MTS Negeri I Manado \\ maladjimmarlina@gmail.com
}

\begin{abstract}
Abstrak
Hasil penelitian menunjukkan rata-rata nilai aktivitas guru dalam mengelola kegiatan pembelajaran 3,42 dengan kategori baik pada siklus I dan 3,55 dengan kategori sangat baik pada siklus II. Aktivitas peserta didik secara klasikal 87,24\% pada siklus I dan 91,90\% pada siklus II. Ketuntasan belajar peserta didik pada siklus I, 74\% dengan DSK 75\% dan Siklus II, 85\% dengan DSK 87\%. Dengan demikian dapat disimpulkan bahwa penerapan model pembelajaran kooperatif tipe TGT pada pembelajaran IPA dapat meningkatkan aktivitas dan hasil belajar peserta didik kelas VIII Taksifi 1 MTs. Negeri 1 Manado.

Kata kunci: Model Pembelajaran Kooperatif tipe TGT, Hasil Belajar
\end{abstract}

\begin{abstract}
The results showed the average value of teacher activity in managing learning activities 3.42 with good category in cycles I and 3.55 with very good category in cycle II. Student activity is $87,24 \%$ classically in cycle I and $91,90 \%$ in cycle II. Completeness learners learners in cycle I, 74\% with DSK 75\% and Cycle II, 85\% with DSK 87\%. Thus it can be concluded that the application of cooperative learning model type TGT on science learning can improve the activity and learning outcomes of students class VIII Taksifi 1 MTs. Negeri 1 Manado.
\end{abstract}

Keywords: Cooperative Learning Model TGT type, Learning Outcomes 


\section{Pendahuluan}

Kurikulum yang diterapkan dan dikembangkan oleh pemerintah saat ini adalah Kurikulum dua ribu tiga belas (K-2013), menyatakan bahwa "proses Pembelajaran pada satuan pendidikan diselenggarakan secara interaktif, inspiratif, menyenangkan, menantang, memotivasi peserta didik untuk berpartisipasi aktif, serta memberikan ruang yang cukup bagi prakarsa, kreativitas, dan kemandirian sesuai dengan bakat, minat, dan perkembangan fisik serta psikologis peserta didik". Hal ini menegaskan bahwa dalam setiap pembelajaran selalu dilakukan perubahan dalam perencanaan, pelaksanaaan maupun evaluasi kegiatan pembelajaran sehingga dapat meningkatkan aktivitas maupun partisipasi peserta didik dalam kegiatan pembelajaran.

Keberhasilan proses belajar mengajar merupakan hal utama yang didambakan guru dalam melaksanakan kegiatan belajar mengajar di madrasah. Komponen utama dalam kegiatan belajar mengajar adalah peserta didik dan guru. Peserta didik menjadi subyek belajar. Namun pada kenyataannya, pembelajaran Teacher Centered Learning ( $\mathrm{TCL}$ ) masih belum bisa dihindari, guru mendominasi proses pembelajaran di kelas. Akibatnya peserta didik lemah dalam memecahkan masalah, partisipasi dalam kegiatan pembelajaran rendah, kerja sama dalam kelompok tidak optimal, kemampuan bertanya dan menjawab pertanyaan rendah. Peserta didik berharap sepenuhnya pada informasi dari guru sehingga pada akhirnya hasil belajar menjadi rendah. Hal yang sama dialami peneliti yang mengajar di kelas VIII taksifi. Kelas taksifi merupakan kelas yang sebagian besar peserta didiknya memiliki inteligen di atas rata-rata (hasil tes IQ), namun pembelajaran teacher centered terpaksa dilaksanakan karena rendahnya partisipasi peserta didik dalam kegiatan pembelajaran.

Hasil observasi peneliti selama semester ganjil, model pembelajaran ceramah yang diselingi dengan diskusi dan pemberian tugas memberikan hasil yang kurang maksimal. Pada kegiatan diskusi terlihat semua peserta didik aktif dan bisa menyelesaikan tugas dengan baik tetapi ketika dilakukan tes akhir menghasilkan prestasi sebagian besar peserta didik rendah. Demikian pula ketika pelaksanaan diskusi kelas, peserta didik yang pintar menguasai pelaksanaan diskusi. Sifat individualis beberapa peserta didik sangat nampak, pembagian tugas sesama anggota tim kurang jelas. Pada saat presentasi kelompok anggota tim hanya berperan dalam membaca atau menjawab pertanyaan yang telah ditulis oleh salah satu anggota yang berperan sebagai ketua tim, sehingga tujuan model pembelajaran tim yang menekankan pada "sukses tim" tidak tercapai dan pembelajaran hanya menjadi seremonial dan tidak bermakna.

Guru sebagai salah satu komponen penting dalam pendidikan, sudah seharusnya memperhatikan dan menciptakan suasana pembelajaran yang inspiratif yang mampu mendorong minat peserta didik untuk senang dan menyukai terhadap pelajaran. Rasa senang akan membuat seseorang sering tidak menyadari bahwa 
dirinya telah melakukan sesuatu dalam jangka waktu yang cukup lama (Ngainun Naim, 2011).

Untuk menciptakan suasana pembelajaran yang inspiratif, aspek pribadi guru dan suasana pembelajaran akan mampu mengakumulasikan potensi dalam diri peserta didik untuk semakin meningkatkan kapasitas dan kapabilitasnya. Modal inilah yang dapat melakukan perubahan baik jangka pendek maupun jangka panjang. Dalam perubahan jangka pendek, peserta didik mampu menjadi peserta didik dengan prestasi yang memuaskan.

Indikator keberhasilan proses belajar mengajar dapat dilihat dari hasil belajar yang dicapai peserta didik. Hasil belajar merupakan cermin dari pengetahuan, keterampilan, dan sikap sering disebut sebagai kemampuan kognitif, afektif, dan psikomotor. Salah satu usaha yang dilakukan guru dengan meningkatkan semangat belajar peserta didik dengan cara mendesain pembelajaran dalam suasana menyenangkan. Suasana belajar dalam keadaan gembira. Suasana gembira artinya bangkitnya minat, adanya keterlibatan penuh, serta terciptanya makna, pemahaman atas materi yang dipelajari, dan nilai yang membahagiakan si pembelajar (Ngainun Naim, 2011).

Hasil observasi dan evaluasi pada kompetensi dasar sebelumnya (hasil UTS), menunjukkan hasil belajar peserta didik 18,5\% memperoleh nilai $\leq 60,37 \%$ memperoleh nilai $61-78,29,6 \%$ memperoleh nilai $79-89$ dan 14,8\% memperoleh nilai 90 - 100. Data tersebut menunjukkan bahwa 44\% peserta didik telah tuntas belajar dan $56 \%$ belum tuntas. Persentase ketidaktuntasan peserta didik cukup tinggi sehingga guru perlu memperbaiki proses pembelajaran. Perbaikan proses pembelajaran ini dilakukan pada aspek penggunaan model pembelajaran. Peneliti merefleksi kembali penggunaan model pembelajaran pada KD sebelumnya dan melakukan perbaikan-perbaikan pada teknik pelaksanaannya.

Berdasarkan data di atas, maka pada semester genap peneliti menggunakan model pembelajaran yang mengikutsertakan semua peserta didik dalam kegiatan pembelajaran. Setiap orang bertanggung jawab terhadap keberhasilan teman anggota timnya. Kegiatan diskusi dan penugasan tetap dilaksanakan dan ditambahkan dengan permainan (game) dan turnamen tim pada akhir pembelajaran, dengan harapan peserta didik tidak terlalu terbebani oleh kompleksnya materi ajar selama kegiatan pembelajaran berlangsung, sehingga mereka dapat menikmati kegiatan belajar mengajar. Dengan adanya permainan tim, peserta didik dipaksakan untuk menjawab pertanyaan dengan benar agar bisa menyumbangkan poin kepada timnya. Melalui permainan tim ini diharapkan dapat meningkatkan aktivitas dan kreativitas peserta didik dalam belajar.

Belum optimalnya hasil belajar peserta didik, bukan hanya disebabkan oleh faktor guru sebagai penyampai pelajaran, tetapi juga peserta didik sebagai subyek dan obyek pembelajaran. Oleh karena itu peneliti merubah model pembelajaran yang mengutamakan penguasaan kompetensi berpusat pada peserta didik, 
memberikan pengalaman belajar relevan dan mengembangkan mental yang kaya dan kuat pada peserta didik, melalui pemberdayaan temannya dalam menyampaikan konsep.

Ada dua faktor yang mempengaruhi keberhasilan belajar peserta didik, yaitu faktor internal dan eksternal. Kedua ini saling mempengaruhi dalam proses belajar individu sehingga menentukan kualitas hasil belajar. Faktor internal adalah faktor yang berasal dari dalam diri peserta didik yang mempengaruhi hasil belajarnya, yaitu faktor jasmaniah, psikologis dan kelelahan. Sedangkan faktor eksternal adalah faktor lingkungan sosial dan non sosial. Salah satu lingkungan sosial madrasah adalah guru, administrasi dan teman-teman sekelas. Disinilah perlunya guru memilih model pembelajaran yang mengaplikasikan antara faktor internal dan faktor eksternal dalam pembelajaran, sehingga dapat menunjang keberhasilan peserta didik.

Salah satu upaya dalam meningkatkan kualitas belajar peserta didik dapat ditempuh dengan menggunakan model yang memvariasikan antara belajar tim dengan permainan. Model pembelajaran ini dikenal dengan model pembelajaran kooperatif tipe Teams Games Tournament (TGT). Pada penelitian ini model pembelajaran kooperatif divariasikan dengan permainan dan turnamen. Model tersebut dipilih karena mempunyai keunggulan berdasarkan hasil penelitian ilmiah yang pernah dilakukan peneliti yaitu pembelajaran dengan menggunakan model kooperatif dapat meningkatkan aktivitas, interaksi, motivasi dan prestasi belajar peserta didik dalam pembelajaran IPA.

Hasil penelitian Slavin (1995) tentang model pembelajaran kooperatif menunjukkan pengaruh positif yang nyata pada hasil belajar siswa kelas 2 sampai kelas 12 dalam seluruh mata pelajaran dan pada seluruh jenis sekolah. (Muhammad Nur dan Prima Retno Wikandari, 2001).

Hasil penelitian Linda Lundgren (1994) menunjukkan bahwa pembelajaran kooperatif memiliki dampak yang amat positif untuk peserta didik yang rendah hasil belajarnya (Muslimin Ibrahim, 2000).

Berdasarkan latar belakang di atas, peneliti menerapkan model pembelajaran kooperatif tipe Teams Games Tournament (TGT) sebagai upaya untuk meningkatkan hasil belajar peserta didik. Adapun judul penelitian ini adalah "Penerapan model pembelajaran kooperatif tipe Teams Games Tournament (TGT) untuk meningkatkan aktivitas dan hasil belajar IPA peserta didik kelas VIII Taksifi 1 MTs. Negeri 1 Manado".

Penelitian ini diharapkan dapat memberikan informasi dan penjelasan tentang hasil penerapan model pembelajaran Kooperatif tipe TGT dalam kegiatan belajar mengajar sehingga dapat meningkatkan aktivitas dan hasil belajar IPA peserta didik kelas VIII Taksifi 1 MTs. Negeri 1 Manado. 


\section{Kajian Teori}

Keberhasilan atau kegagalan dalam proses belajar mengajar merupakan sebuah ukuran atas proses pembelajaran. Belajar dikatakan berhasil apabila diikuti ciri-ciri (1) Daya serap terhadap bahan pelajaran yang diajarkan mencapai prestasi tinggi, baik secara individu maupun kelompok; (2) Perilaku yang digariskan dalam tujuan pembelajaran telah dicapai oleh peserta didik, baik secara individual maupun kelompok; (3) Terjadinya proses pemahaman materi yang secara sekuensial mengantarkan pada materi tahap berikutnya (Muslimin Ibrahim, 2000).

Model Pembelajaran Kooperatif (Cooperatif Learning) memiliki beberapa tipe yang ditandai dengan adanya struktur tugas, struktur tujuan dan struktur penghargaan (reward) (Muslimin Ibrahim, 2000). Pembelajaran kooperatif menuntut kerjasama peserta didik dan saling ketergantungan dalam struktur tugas, tujuan dan hadiah. Salah satu tipe pembelajaran kooperatif tipe TGT (Team-GamesTournament) atau Turnamen Game Tim.

Model pembelajaran Team-Games-Tournament (TGT) adalah salah satu tipe model pembelajaran kooperatif yang mudah diterapkan, melibatkan seluruh aktivitas seluruh peserta didik tanpa harus ada perbedaan status, melibatkan peran peserta didik sebagai tutor sebaya dan mengandung unsur permainan dan reinforcement. Aktivitas belajar dengan permainan memungkinkan peserta didik belajar lebih rileks disamping menumbuhkan tanggung jawab, kejujuran, kerja sama, persaingan sehat dan keterlibatan belajar. Pada mulanya dikembangkan oleh David DeVries dan Keith Edwards, merupakan metode pembelajaran pertama dari John Hopkins (Robert E. Slavin, 2011). Metode ini menggunakan pelajaran yang sama dengan yang disampaikan guru dan tim kerja yang sama seperti dalam STAD, tetapi mengganti kuis dengan turnamen mingguan, dimana peserta didik memainkan game akademik dengan anggota tim lain untuk menyumbangkan poin bagi skor timnya. Peserta didik memainkan game ini bersama tiga orang pada "meja turnamen", di mana ketiga peserta dalam satu meja turnamen ini adalah peserta didik yang memiliki rekor nilai IPA terakhir sama. Sebuah prosedur "menggeser kedudukan" membuat permainan ini cukup adil. Peraih skor tertinggi dalam tiap meja turnamen akan mendapatkan 60 poin untuk timnya, tanpa menghiraukan dari meja mana ia mendapatkannya; ini berarti bahwa mereka yang berprestasi rendah bermain dengan yang berprestasi rendah juga dan yang berprestasi tinggi bermain dengan yang berprestasi tinggi; keduanya memiliki kesempatan yang sama untuk sukses. Sama seperti dalam STAD, tim dengan tingkat kinerja tertinggi mendapatkan sertifikat atau bentuk penghargaan tim lainnya.

TGT memiliki banyak kesamaan dengan STAD, tetapi menambahkan dimensi kegembiraan yang diperoleh dari penggunaan permainan. Teman satu tim akan saling membantu dalam mempersiapkan diri untuk permainan dengan mempelajari lembar kegiatan dan menjelaskan masalah-masalah satu sama lain. Pembelajaran kooperatif tipe TGT memiliki komponen (1) Presentasi di Kelas (Penyajian Kelas); (2) 
Kelompok (tim); (3) Game; (4) Turnamen; dan (5) Rekognisi Tim (Penghargaan Kelompok).

\section{Metode Penelitian}

Bentuk penelitian tindakan kelas yang dipilih peneliti adalah Penelitian Tindakan Guru sebagai Peneliti. Guru berperan sebagai peneliti yang sekaligus praktisi pembelajaran (Suharsimi Arikunto, 2014). Sumber data dalam penelitian tindakan ini berasal dari guru dan peserta didik (responden) secara langsung. Data yang diperoleh bersifat kualitatif dan kuantitatif. Metode pengumpulan data yang digunakan yaitu teknik observasi (pengamatan), dan tes. Analisis data yang digunakan yaitu analisis kualitatif dan untuk data teknik analisis statistik deskriptif.

\section{Pembahasan}

Penelitian tindakan kelas dilaksanakan selama 2 siklus dan masing-masing siklus 5 kali pertemuan termasuk evaluasi setiap siklus. Menurut Slavin, TGT tidak secara otomatis menghasilkan skor yang dapat digunakan untuk menghitung nilai individual peserta didik (Robert E. Slavin, 2011). Oleh karena itu, pada akhir siklus peneliti melakukan ulangan formatif. Materi pelajaran yang menjadi fokus penelitian yaitu system ekskresi pada manusia dan getaran, gelombang dan bunyi.

Hasil pengamatan aktivitas guru dalam kegiatan belajar mengajar pada siklus I menunjukkan rata-rata skor nilai 3,42 atau 85,61\% kategori penilaian baik, dan pada siklus II, rata-rata skor nilai 3,55 atau $88,64 \%$ kategori penilaian sangat baik. Hasil pengamatan aktivitas peserta didik pada setiap tim dalam kegiatan belajar mengajar menunjukkan nilai persentase rata-rata pada siklus I $87,24 \%$ dan pada siklus II, 91,90\%. Sedangkan ketuntasan belajar dan daya serap kurikulum (DSK) peserta didik pada siklus I, 74\% dengan DSK 75\%, pada siklus II ketuntasan belajar peserta didik $85 \%$ dengan DSK $87 \%$.

Peningkatan nilai hasil penelitian tindakan kelas tidak terlalu tinggi dikarenakan peserta didik kelas VIII Taksifi telah terbiasa melaksanakan pembelajaran kooperatif sehingga diskusi kelompok berjalan dengan baik namun nilai mereka rendah pada saat pelaksanaan games dan turnamen, sehingga diperlukan bimbingan yang intensif dari guru.

Berdasarkan data di atas, dapat disimpulkan bahwa "Penerapan model pembelajaran kooperatif tipe TGT dapat meningkatkan aktivitas belajar dan hasil belajar IPA peserta didik di kelas VIII Taksifi 1. Namun terdapat beberapa hal yang perlu diperhatikan oleh guru dalam pembelajaran kooperatif tipe TGT yaitu: (1) Dalam menyusun skenario pembelajaran setiap siklus, diperlukan perencanaan yang matang, sehingga penggunaan waktu lebih efisien; (2) RPP Kooperatif tipe TGT dibuat serinci mungkin untuk tiap tahapan; (3) Membutuhkan pengelolaan kelas yang maksimal, terutama pada saat games dan turnamen; (4) Pembimbingan guru harus intensif pada saat pelaksanaan games dan turnamen; (5) Kesabaran dan kreativitas guru sangat diperlukan pada kegiatan pembelajaran ini, karena faktor 
kebisingan peserta didik selama pelaksanaan games dan turnamen tidak dapat dihindari.

\section{Kesimpulan}

Penerapan model pembelajaran Kooperatif tipe TGT dapat meningkatkan aktivitas dan hasil belajar IPA peserta didik kelas VIII Taksifi 1 MTs. Negeri 1 Manado. Peningkatan aktivitas peserta didik dalam mengkonstruksi pengetahuan mereka, peserta didik memiliki kemampuan menganalisis permasalahan serta mengungkapkannya dan Berbagi dengan teman-teman anggota timnya. Model pembelajaran kooperatif tipe TGT perlu dikembangkan dan diujicobakan dalam kegiatan pembelajaran guna menghindari kebosanan peserta didik dalam belajar.

\section{Referensi}

Muhammad Nur dan Prima Retno Wikandari. (2001). Pengajaran berpusat kepada Peserta didik dan Pendekatan Konstruktivis dalam Pengajaran. Surabaya: University Press. Pusat studi Matematika dan IPS sekolah Unesa.

Muslimin Ibrahim, D. (2000). Pembelajaran Kooperatif. Surabaya: University Press. Pusat studi Matematika dan IPS sekolah Unesa.

Ngainun Naim. (2011). Menjadi Guru Inspiratif. Yogyakarta: Pustaka Pelajar.

Robert E. Slavin. (2011). Cooperative Learning: Teori, Riset dan Praktik. Bandung: Nusa Media.

Suharsimi Arikunto. (2014). Penelitian Tindakan Kelas. Jakarta: Bumi Aksara. 